\title{
An Option Based Model of Rational Residential Mortgage Default
}

\author{
Guangqiang Wei ${ }^{1,2}$ \\ ${ }^{1}$ Shandong Jiaotong University, Jinan, China \\ ${ }^{2}$ Shandong University, Jinan, China \\ Correspondence: Guangqiang Wei, Shandong Jiaotong University, No.5001, Haitang Road, Changqing University \\ Science \& Technology Park, Jinan City 250357, Shandong Province, China. E-mail: gavinwei2006@163.com
}

Received: January 4, 2014

Accepted: January 15, 2014

Online Published: April 21, 2014

doi:10.5430/bmr.v3n2p28

URL: http://dx.doi.org/10.5430/bmr.v3n2p28

\begin{abstract}
For recent years, the subject of residential mortgage default has claimed the attention of scholars, policy analysts, government officials and common consumers. This article analyzed the relation between the possibility of rational residential mortgage default and the market value of the house, and on the basement of option theory, suggested a model to estimate the possibility of rational default. Using this model, holders of residential mortgage portfolios could predict the possibility of rational default.
\end{abstract}

Keywords: Residential mortgage, Rational default, Option theory, Possibility of default

\section{Introduction}

The residential mortgage appeared at the end of 1980's in China, and along with the reform of housing system, residential mortgage business has developed rapidly. Commercial banks' mortgage business increased greatly in not only the breadth but also the depth, the residential mortgage expanded rapidly. At the end of 1997, China's commercial banks' mortgage loans was only 19 billion Yuan, but by the three quarter of 2011 the balance had turn out to be 5.65 trillion Yuan, expanded nearly 300 times. The scale is large, development speed is also very quick, and the influence on China's financial and economic development is also growing with each passing day. International experience shows that the residential mortgage loan default risk usually exposes within $5 \sim 10$ years. At present, the defect ratio of the commercial banks' residential mortgage loans has increased; the overall quality of the residential mortgage has also declined. Therefore, to research our commercial banks' residential mortgage default risk systematically and thoroughly has very important theory and realistic meaning. This article analyzed the relation between the possibility of rational residential mortgage default and the market value of the house, and on the basement of option theory, suggested a model to estimate the possibility of rational default. The objective of the study is to find out which factors will affect the possibility of rational default.

\section{Rational residential mortgage default and option theory}

Along with the option theory development, many scholars of residential mortgage default also introduced it to explain the default behavior. The first application of option theory in residential mortgage default risk is made by Foster and Van Order (1984).this model views default as a put option, allowing the borrower to sell the house to the lender for the value of the mortgage at the beginning of each payment period. Ideally, borrower will exercise this option and default whenever the value of the house falls below the mortgage value. Using data on FHA default rates from 1960 through 1978, Foster and Van Order (1984) estimated loan-to-value ratios over time and used this information create a number of variables. Overall, the option-based model of default worked remarkable well: it explained over $90 \%$ of the variance using just the equity variables.

\section{The model to estimate the possibility of rational default}

The residential default risk is the result of the borrower's rational choice to maximize his total utility. So when the house value falls below the balance of mortgage loan, the net equity of the house becomes negative, then he will stop the repayment. So the default risk will appear under the condition of:

$$
V_{t}<M_{t}
$$


Where $V_{t}$ represents the market value of the house bought by the borrower with the help of residential mortgage at time t; $M_{t}$ represents the balance of the residential mortgage loan at time t.

Thus the possibility of default $P_{t}$ equals the possibility of that the market value of the house is smaller than the balance of the residential mortgage loan:

$$
P_{t}=P\left(V_{t}<M_{t}\right)
$$

The value of the house, $V_{t}$, is assumed to follow a standard lognormal process, that is $\frac{d V_{t}}{V_{t}}=u d t+b d z$ with $u$ and $b$ representing the instantaneous total expected return and proportionate volatility respectively and $d z$ representing a standard Wiener process. So we get:

$$
V_{t}=V_{0} \exp \left\{\left[u-\frac{b^{2}}{2}\right] t+b \sqrt{t} Z_{t}\right\}
$$

Where $V_{0}$ represents the initial value of the house at time $\mathrm{t}=0$.

Using logarithmic transformation the function turns out to be:

$$
\ln V_{t}=\ln V_{0}+\left(u-\frac{b^{2}}{2}\right) t+b \sqrt{t} Z_{t}
$$

Assuming that the borrower adopt equal installments of principal and interest method to amortize residential mortgage loans, the outstanding balance in period t $M_{t}$ depends on the initial market value of the house $V_{0}$, the initial value of the loan-to-value ratio $L / V_{0}$, the interest rate $\mathrm{r}$ of the mortgage loan, the repayment period $\mathrm{T}$ and the current repayment period $\mathrm{t}$, can be expressed as follows:

$$
\mathrm{M}_{\mathrm{t}}=\mathrm{V}_{0}\left[\mathrm{~L} / \mathrm{V}_{0}\right]\left[\frac{1-(1+\mathrm{r})^{\mathrm{t}-\mathrm{T}}}{1-(1+\mathrm{r})^{-\mathrm{T}}}\right] \quad \mathrm{t}=1,2,3, \ldots, \mathrm{T}
$$

Using logarithmic transformation the function turns out to be:

$$
\ln \mathrm{M}_{\mathrm{t}}=\ln \mathrm{V}_{0}+\ln \mathrm{L} / \mathrm{V}_{0}+\ln \frac{1-(1+\mathrm{r})^{\mathrm{t}-\mathrm{T}}}{1-(1+\mathrm{r})^{-\mathrm{T}}} \quad \mathrm{t}=1,2,3, \ldots, \mathrm{T}
$$

Thus the possibility of default $P_{t}$ can be converted to be:

$$
\begin{gathered}
P_{t}=P\left(V_{t}<M_{t}\right)=P\left(\ln V_{t}<\ln M_{t}\right)=P\left[\ln V_{0}+\left(u-\frac{b^{2}}{2}\right) t+b \sqrt{t} Z_{t}<\ln \mathrm{V}_{0}+\ln \mathrm{L} / \mathrm{V}_{0}+\ln \frac{1-(1+\mathrm{r})^{\mathrm{t}-\mathrm{T}}}{1-(1+\mathrm{r})^{-\mathrm{T}}}\right] \\
=P\left(Z_{t}<-\frac{\left(u-\frac{b^{2}}{2}\right) t-\ln \mathrm{L} / \mathrm{V}_{0}-\ln \frac{1-(1+\mathrm{r})^{\mathrm{t}-\mathrm{T}}}{1-(1+\mathrm{r})^{-\mathrm{T}}}}{b \sqrt{t}}\right)=N(-d)
\end{gathered}
$$

Where $N(*)$ represents a standard normal cumulative distribution and

$$
d=\frac{\left(u-\frac{b^{2}}{2}\right) t-\ln \mathrm{L} / \mathrm{V}_{0}-\ln \frac{1-(1+\mathrm{r})^{\mathrm{t}-\mathrm{T}}}{1-(1+\mathrm{r})^{-\mathrm{T}}}}{b \sqrt{t}} .
$$

\section{Conclusion}

This article analyzed the residential mortgage default from the perspective of option theory and constructed a model to predict the possibility of default risk, making some theoretical contribution to the risk control process of the commercial banks. To further the research, some empirical evidence should be provided to make the conclusion more solid.

\section{Acknowledgement}

The author thanks the Shandong Jiao tong University research fund No. R201320. 


\section{References}

Black, Fisher \& Myron Scholes. (1973). The Pricing of Options and Corporate Liabilities, Journal of Political Economy, 81: 637-654. http://dx.doi.org/10.1086/260062

Foster C \& R Van Order. (1984). An Option Based Model of Mortgage Default, Housing Finance Review, 3(4):351-372.

Kau, James B., Donald C. Keenan, Walter J. Muller, III, \& James F. Epperson. (1990). The Valuation and Analysis of Adjustable Rate Mortgages, Management Science, 36: 1417-1431. http://dx.doi.org/10.1287/mnsc.36.12.1417

Merton, Robert. (1973). Theory of Rational Optional Pricing, Bell Journal of Economics and Management Science, 4: 141-183. http://dx.doi.org/10.2307/3003143 